\title{
A family with complement factor $D$ deficiency
}

\author{
Douwe H. Biesma, ${ }^{1}$ André J. Hannema, ${ }^{2}$ Heleen van Velzen-Blad, ${ }^{3}$ \\ Leontine Mulder, ${ }^{3}$ Rob van Zwieten, ${ }^{2}$ Irma Kluijt, ${ }^{4}$ and Dirk Roos ${ }^{2,5}$ \\ ${ }^{1}$ Department of Internal Medicine, St. Antonius Hospital, Nieuwegein, The Netherlands \\ ${ }^{2}$ Central Laboratory of the Netherlands Blood Transfusion Service, Amsterdam, The Netherlands \\ ${ }^{3}$ Department of Medical Microbiology and Immunology, St. Antonius Hospital, Nieuwegein, The Netherlands \\ ${ }^{4}$ Department of Clinical Genetics, and \\ ${ }^{5}$ Laboratory for Experimental and Clinical Immunology, Academic Medical Center, University of Amsterdam, \\ Amsterdam, The Netherlands
}

Address correspondence to: Douwe H. Biesma, Department of Internal Medicine,

St. Antonius Hospital, PO Box 2500, 3430 EM Nieuwegein, The Netherlands.

Phone: 31-30-6099111; Fax: 31-30-6056357; E-mail: d.biesma@antonius.net.

Received for publication December 15, 2000, and accepted in revised form June 11, 2001.

A complement factor $\mathrm{D}$ deficiency was found in a young woman who had experienced a serious Neisseria meningitidis infection, in a deceased family member with a history of meningitis, and in three relatives without a history of serious infections. The patient and these three relatives showed a normal activity of the classical complement pathway, but a very low activity of the alternative complement pathway and a very low capacity to opsonize Escherichia coli and N. meningitidis (isolated from the patient) for phagocytosis by normal human neutrophils. The alternative pathway-dependent hemolytic activity and the opsonizing capacity of these sera were restored by addition of purified factor $\mathrm{D}$. The family had a high degree of consanguinity, and several other family members exhibited decreased levels of factor $D$. The gene encoding factor $D$ was found to contain a point mutation that changed the TCG codon for serine 42 into a TAG stop codon. This mutation was found in both alleles of the five completely factor D-deficient family members and in one allele of 21 other members of the same family who had decreased or low-normal factor $D$ levels in their serum. The gene sequence of the signal peptide of human factor $D$ was also identified. Our report is the first, to our knowledge, to document a Factor $D$ gene mutation. The mode of inheritance of factor $\mathrm{D}$ deficiency is autosomal recessive, in accordance with the localization of the Factor $D$ gene on chromosome 19. Increased susceptibility for infections in individuals with a partial factor D deficiency is unlikely.

J. Clin. Invest. 108:233-240 (2001). DOI:10.1172/JCI200112023.

\section{Introduction}

The complement system consists of more than 20 plasma proteins and plays an important role in the defense against microorganisms (1). Activation of the classical or the alternative pathway results in the cleavage of $\mathrm{C} 3$, the central component of the system. In the alternative pathway, the spontaneous hydrolysis product iC3 (i.e., C3 with intact peptide chains but with a hydrolyzed thioester) complexes with factor $\mathrm{B}$ in the presence of magnesium ions, which allows factor $\mathrm{D}$ to cleave factor $\mathrm{B}$ bound to $\mathrm{iC} 3$, thus producing the fluid-phase, alternative $\mathrm{C} 3$ convertase $\mathrm{iC} 3 \mathrm{Bb}$. This $\mathrm{iC} 3 \mathrm{Bb}$ convertase generates $\mathrm{C} 3 \mathrm{~b}$ from native $\mathrm{C} 3$ and accounts for the spontaneous "tick-over" of $\mathrm{C} 3$ in plasma. The C3b generated in this way may bind to a bacterial surface, where it is protected from degradation by factors $\mathrm{I}$ and $\mathrm{H}$ and can bind factor $\mathrm{B}$ to give the $\mathrm{C} 3 \mathrm{bB}$ complex. Upon cleavage of factor $\mathrm{B}$ in this complex by factor $\mathrm{D}$, another $\mathrm{C} 3$ convertase is generated, which cleaves additional C3. This convertase $\mathrm{C} 3 \mathrm{bBb}$ can become stabilized by binding properdin. $\mathrm{C} 3 \mathrm{bBbP}$ bound to bacteria generates many C3b molecules, which in their turn can bind to the nearby bacterial surface and be protected from degradation as a result. Bound $\mathrm{C} 3 \mathrm{~b}$ molecules can either remain as such and act as opsonins for enhanced phagocytosis of the bacteria by phagocytic cells, they can bind new molecules of factor $\mathrm{B}$ to generate new $\mathrm{C} 3$ convertase complexes in the amplification loop of $\mathrm{C} 3$ activation, or they can combine with factor $\mathrm{B}$ and another molecule of $\mathrm{C} 3 \mathrm{~b}$ to generate the $\mathrm{C} 5$ convertase $\mathrm{C} 3 \mathrm{bBb} 3 \mathrm{~b}$. This last enzyme binds and cleaves C5, with the subsequent generation of $\mathrm{C} 5 \mathrm{a}$ and $\mathrm{C} 5 \mathrm{~b}$. Interaction of $\mathrm{C} 5 \mathrm{~b}$ with the terminal components of the complement system $\mathrm{C} 6, \mathrm{C} 7, \mathrm{C} 8$, and $\mathrm{C} 9$ results in the formation of the "membrane attack complex."

Factor D fulfills an essential role in the initiation and propagation of the alternative pathway of complement activation and in the amplification loop of $\mathrm{C} 3$ activation. Factor $\mathrm{D}$ is a serine protease of about $24 \mathrm{kDa}$ that circulates in the blood as a constitutively active enzyme. It is synthesized by fat cells and macrophages (2). Deficiencies have been described for almost all components of the complement system, including factor D (3). Increased susceptibility to (recurrent) Neisseria infections has been observed in patients with deficiencies in terminal or alternative pathway components (4). We describe a patient suffering from meningococcemia caused by $N$. 


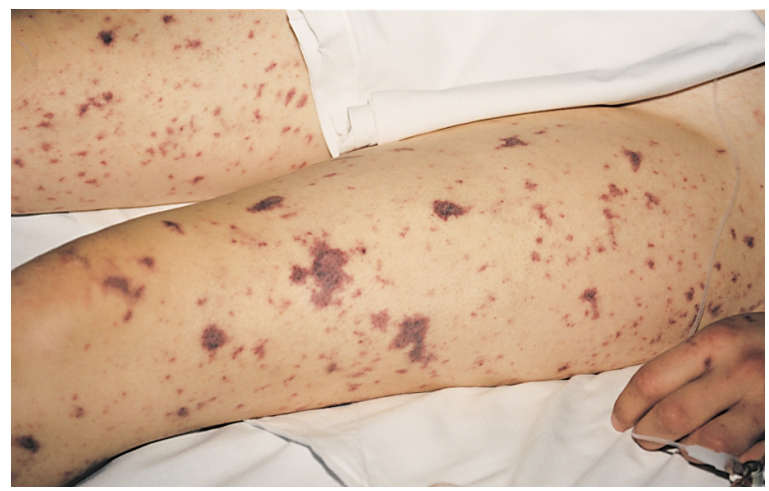

Figure 1

Skin changes in the propositus.

meningitides and a deceased family member with a history of bacterial meningitis. Those two patients and three living family members had a complete factor D deficiency; several other family members had a partial factor $\mathrm{D}$ deficiency. Further investigations revealed the first mutation in the complement factor $\mathrm{D}$ gene.

Case report. A 23-year-old, nonobese Dutch woman was referred to our hospital because she suffered from a collapse accompanied by a sudden onset of fever and skin changes. Her medical history revealed no abnormalities; there were no records of recurrent (bacterial) infections in the patient, in her nonidentical twin sister, or in the other living family members at that time. At admission, the patient's blood pressure was $80 / 60 \mathrm{mmHg}$, and the oxygen saturation of her blood was $86 \%$. Several petechiae and subcutaneous ecchymoses were noticed (Figure 1). Stiff neck muscles were not found.

The hemoglobin level was $6.9 \mathrm{mmol} / \mathrm{l}$ (normal: $7.0-10.0 \mathrm{mmol} / \mathrm{l}$ ), the white blood cell count was $10.1 \times$ $10^{9} / 1$ (normal: $4.0-10.0 \times 10^{9} / 1$ ) with $24 \%$ band forms, the platelet concentration was $37 \times 10^{12} / 1$ (normal $\left.150-450 \times 10^{12} / 1\right)$, the activated partial thromboplastin time was 102 seconds (normal: 25-38 seconds), the fib- rinogen level was $0.6 \mathrm{~g} / 1$ (normal: $1.7-3.3 \mathrm{~g} / \mathrm{l}$ ), and the semiquantitative analysis of $\mathrm{D}$ dimers was strongly positive (++++; normal: negative). Her clinical condition deteriorated rapidly with severe hypotension and hypoventilation, which required mechanical ventilation and pressure support at the intensive care unit. The patient was immediately treated with intravenous penicillin $\mathrm{G}$ and stress-dose steroids because the clinical picture was highly suggestive for the Waterhouse-Friderichsen syndrome. Blood and cerebrospinal fluid cultures were found to be positive for Neisseria meningitidis serogroup B (type 15, subtype P1.5). Although the clinical course was complicated by a progressive decline of the renal function and diffuse intravascular coagulation, the patient did recover completely. During her recovery, she did not receive prophylactic antibiotics. We decided to perform a complement system analysis to search for a complement factor deficiency in this family. The pedigree (Figure 2) shows a high degree of consanguinity, which renders an autosomal recessive inheritance very likely. The patient and her family members gave informed consent for the study protocol.

During the ongoing search for other factor D deficiencies in this family, we found very recently a fifth homozygous individual (III-18 in Figure 2). This man, born in 1929, survived a bacterial meningitis of unknown origin during his military service in 1949 and developed in January 2000 a fatal pneumonia and meningitis caused by Streptococcus pneumoniae. The diagnosis of factor D deficiency was made on DNA, obtained from stored liquor. The two daughters of this patient are heterozygous for factor $\mathrm{D}$ deficiency.

\section{Methods}

Complement assays. The activities of the classical (CH50) and alternative (AP50) complement pathways were determined as described $(5,6)$ and expressed as a percentage of the values found with a pool of serum obtained from 30 healthy donors. The concentrations

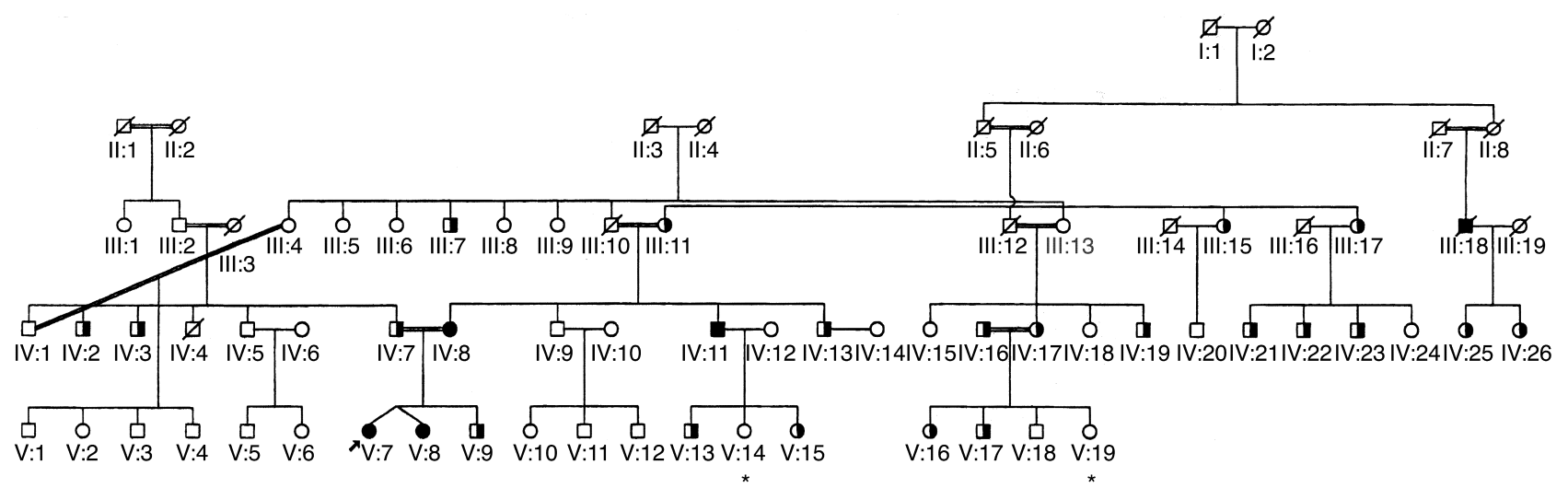

Figure 2

Pedigree of the family with factor D deficiency. Heterozygotes and homozygotes for the C125A (Ser42 $\rightarrow$ stop) mutation are indicated by half-filled and filled symbols, respectively. Open symbols indicate family members with wild-type C125 configuration. Symbols with a slash indicate deceased and (except for III:18) noninvestigated family members; symbols with an asterisk indicate living, noninvestigated family members. Double lines indicate consanguineous marriages. The propositus is indicated by an arrow. 
a
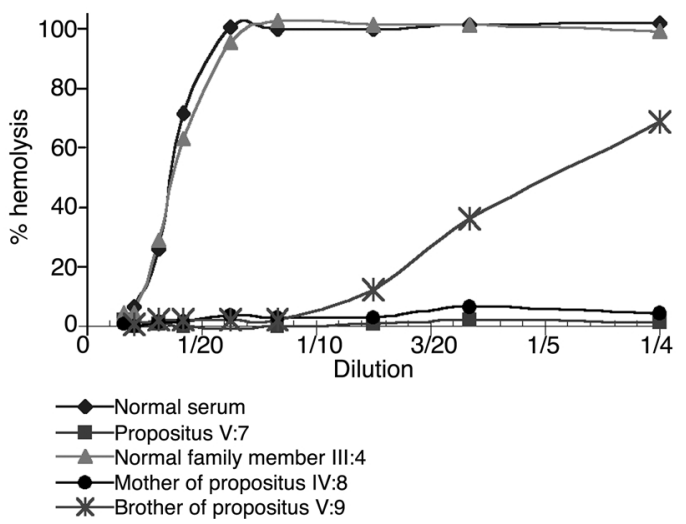

b

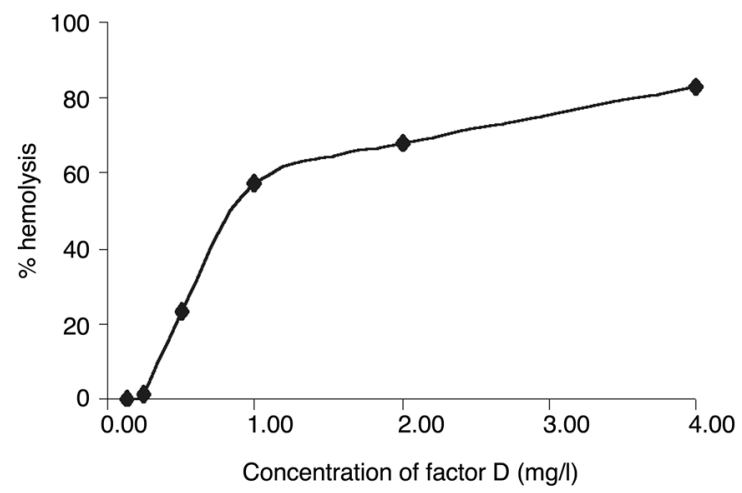

Figure 3

Factor D activity of normal serum and partially or completely factor D-deficient serum. (a) Depiction of the factor D activity of the various sera diluted with different amounts of factor D-depleted serum (dilutions from 1:50 to 1:4). Diamonds, normal serum; squares, propositus $\mathrm{V}: 7$; triangles, normal family member III:4; circles, mother of the propositus IV:8; asterisks, brother $\mathrm{V}: 9$ of the propositus. (b) The restoration of factor $\mathrm{D}$ activity in the serum of the propositus by addition of different amounts of purified factor $D$. The results shown in these figures are representative of three independent experiments.

of the complement $\mathrm{C} 4$ and $\mathrm{C} 3$ were measured by an immunoturbidimetric assay on a Cobas Fara centrifugal autoanalyzer.

Factor $D$ assays. Polyclonal sheep Ab's against factor D (The Binding Site, Birmingham, United Kingdom) were conjugated to $\mathrm{NaIO}_{4}$-activated horseradish peroxidase (HRP). Another portion of these Ab's was coupled to biotin. These reagents were used to determine the concentration of factor D by an ELISA based on the Boehringer Mannheim Biochemicals Inc. (Mannheim, Germany) Enzymun-Test system ES 300. Streptavidin-coated tubes were incubated with a mixture of $50 \mu \mathrm{l}$ of diluted serum and $450 \mu \mathrm{l}$ of a 1:1000 dilution of the anti-factor $\mathrm{D}$ biotin conjugate. After a 60 -minute incubation at $37^{\circ} \mathrm{C}$, the tubes were washed and a 1:500 diluted HRP-conjugated anti-factor $\mathrm{D}$ was added; the tubes were then incubated for a further hour at $37^{\circ} \mathrm{C}$. After washing, $500 \mu \mathrm{l}$ of ABTS substrate solution was added and incubated for 30 minutes at $37^{\circ} \mathrm{C}$. The samples' OD was measured at $450 \mathrm{~nm}$. Normal human serum was calibrated with the purified fac- tor D preparation from Quidel Corp. (San Diego, California, USA) and was used thereafter as a standard for the factor D ELISA.

Factor D-depleted serum for testing factor D activity was prepared by applying normal human serum to a BioRex-70 column and collecting the breakthrough fraction (7). Dilutions of serum or purified factor D (50 $\mu \mathrm{l})$ were tested in round-bottomed microtiter plates with factor D-depleted serum $(50 \mu \mathrm{l})$ in the presence of $50 \mu \mathrm{l}$ of veronal buffer with MgEGTA and $50 \mu \mathrm{l}$ of rabbit erythrocyte suspension. After incubation for 1 hour on a laboratory shaker at $37^{\circ} \mathrm{C}$, the plate was centrifuged, and the OD's of the supernatants were measured in flat-bottomed plates at $412 \mathrm{~nm}$.

Opsonization assay. The capacity of sera to promote the phagocytosis of Escherichia coli by normal human neutrophils was determined in a microscopic assay. In brief, $10^{7}$ serum-resistant $E$. coli 054 were mixed with $10^{6}$ neutrophils in a HEPES medium $(132 \mathrm{mM} \mathrm{NaCl}$, $20 \mathrm{mM}$ HEPES, $6 \mathrm{mM} \mathrm{KCl}, 1 \mathrm{mM} \mathrm{MgSO} 4,1 \mathrm{mM}$ $\mathrm{CaCl}_{2}, 1.2 \mathrm{mM} \mathrm{K}_{2} \mathrm{HPO}_{4}, 5.5 \mathrm{mM}$ glucose, $0.5 \% \mathrm{wt} / \mathrm{vol}$ human albumin, and 5 mM MgEGTA, pH 7.4) and different concentrations of human serum in a total volume of $100 \mu \mathrm{l}$. These mixtures were incubated for 30 minutes at $37^{\circ} \mathrm{C}$ in a shaking water bath. Samples of $10 \mu \mathrm{l}$ were then diluted with $40 \mu \mathrm{l}$ of ice-cold PBS containing $10 \%$ (vol/vol) albumin. About $25 \mu \mathrm{l}$ of each sample were spun onto a microscope slide in a cytocentrifuge and then stained with May-Grünwald/ Giemsa. Forty cells per slide were counted for their content of bacteria. The results were expressed as the mean number of bacteria per cell. The same procedure was followed for the opsonization assay of N. meningitidis (isolated from the cerebrospinal fluid of the patient), except that the MgEGTA was left out of the reaction mixture (no opsonization was observed in the presence of MgEGTA).

cDNA PCR. RNA was isolated from blood leukocytes by the method of Chirgwin et al. (8), followed by cDNA synthesis (9). Factor D cDNA (2) was amplified in three overlapping fragments of about $400 \mathrm{bp}$. The sense primers were labeled with a $-21 \mathrm{M} 13$ flag (Table 1). The PCR was performed in an Air Thermo Cycler (Idaho Technology, Idaho Falls, Idaho, USA) in sealed glass capillaries containing $4.9 \mu \mathrm{l}$ of demineralized water, $3.0 \mu \mathrm{l}$ of GC-buffer $(286 \mathrm{mM}$ tricine, $107 \mathrm{mM}$ K-acetate, $25 \mathrm{mM} \mathrm{MgSO}_{4}, 35.7$ \% DMSO, $2.68 \mu \mathrm{g} / \mathrm{ml} \mathrm{BSA}$ ), $0.6 \mu \mathrm{l}$ of 7 -deaza-dNTP solution 75\% (3.75 mM 7-deaza-dGTP, $1.25 \mathrm{mM}$ dGTP, $5 \mathrm{mM}$ dATP, $5 \mathrm{mM}$ dCTP, $5 \mathrm{mM}$ dTTP; Boehringer Mannheim Biochemicals Inc.), $0.2 \mu \mathrm{l}$ of anti-Taq DNA polymerase $(7 \mu \mathrm{M}$; CLONTECH Laboratories Inc., Palo Alto, California, USA), $0.2 \mu \mathrm{l}$ of Taq DNA polymerase (5 U/ $\mu \mathrm{l}$; Promega Corp., Madison, Wisconsin, USA), $1 \mu \mathrm{l}$ of a $1-\mu \mathrm{M}$ solution of each primer, and $2 \mu \mathrm{l}$ of sample solution containing approximately $2 \mathrm{ng} / \mu \mathrm{l} \mathrm{cDNA}$. The cycle conditions were $10 \mathrm{sec}-$ onds at $96^{\circ} \mathrm{C}, 10$ seconds at $60^{\circ} \mathrm{C}$, and 40 seconds at $72^{\circ} \mathrm{C}$, for 40 cycles at slope 9 . 


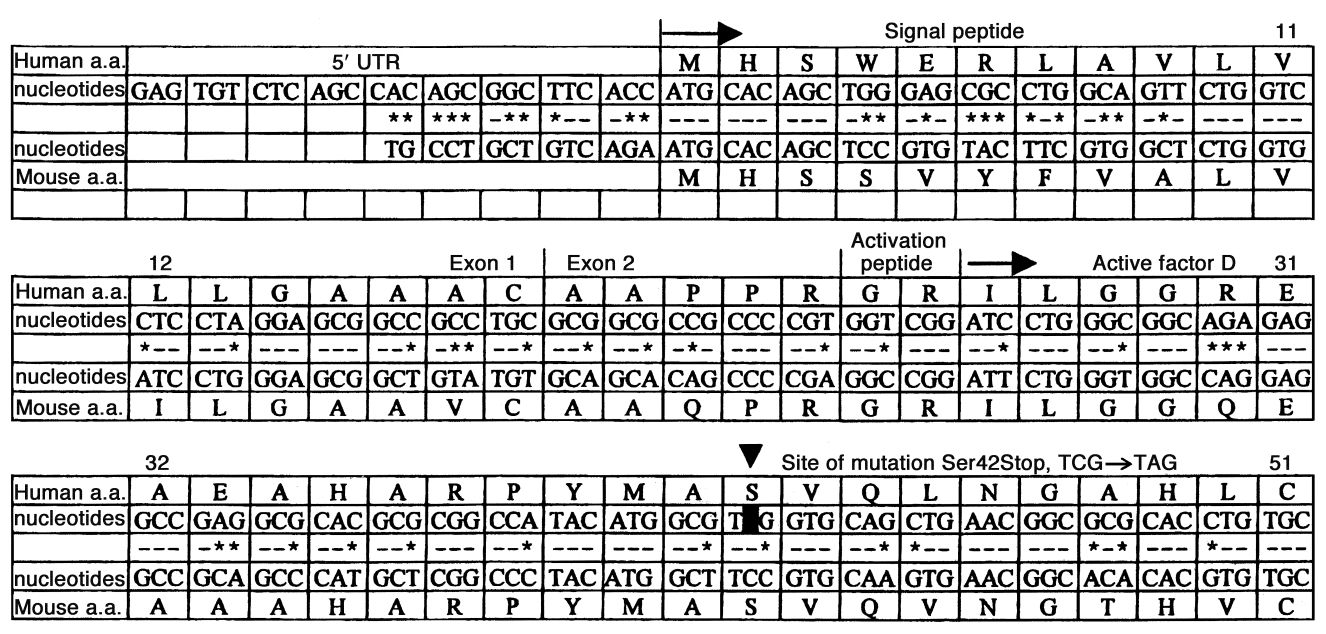

\section{Figure 4}

The $5^{\prime}$ sequence of human and mouse factor D cDNA. The mouse sequence is from ref. 17. Identity between mouse nucleotides and human nucleotides are indicated by dashes, differences by asterisks. 5' UTR, $5^{\prime}$ untranslated region; first arrow, start of protein synthesis; second arrow, start of circulating protein sequence; arrowhead, position of mutation. The signal peptide runs from amino acid 1 (methionine) to amino acid 23 (arginine); the activation peptide comprises amino acids 24 (glycine) and 25 (arginine).

For the amplification of fragment 3, GC-buffer and 7-deaza-dNTP were omitted; Promega Thermophilic DNA polymerase $10 \times$ buffer $(100 \mathrm{mM}$ Tris- $\mathrm{HCl}, \mathrm{pH}$ 9.0, $500 \mathrm{mM} \mathrm{KCl}, 1 \% \mathrm{vol} / \mathrm{vol}$ Triton $\mathrm{X}-100)$ and $0.6 \mu \mathrm{l}$ of dNTP solution ( $5 \mathrm{mM}$ of each dNTP) were used instead. To improve the yield, the cDNA amplification product obtained with primers $2 \mathrm{~S}$ and $3 \mathrm{AS}$ was used as a template $(1 \mu \mathrm{l})$ for the amplification of fragment 3 . Similarly, the cDNA amplification product obtained with primers 1S and 1AS (fragment 1) was used as a template for the amplification of fragments $1 \mathrm{a}$ and $1 \mathrm{~b}$.

Genomic PCR. Genomic DNA was isolated from leukocytes with the Puregene kit (Gentra Systems Inc., Minneapolis, Minnesota, USA) or from blood plasma with a QIA-Amp blood kit 50 (QIAGEN GmbH, Hilden, Germany). PCR was performed in glass capillaries containing $1.1 \mu \mathrm{l}$ of water, $2 \mu \mathrm{l}$ of $10 \times$ BSA solution $(2.5 \mu \mathrm{g} / \mu \mathrm{l}$ BSA; Sigma Chemical Co., St. Louis, Missouri, USA), 1.5 $\mu \mathrm{l}$ of Promega Thermophilic DNA polymerase in $10 \times$ buffer, $0.9 \mu \mathrm{l}$ of $\mathrm{MgCl}_{2}(25 \mathrm{mM}), 0.6 \mu \mathrm{l}$ of 7-deaza-dNTP solution $75 \%$ (see above), $0.2 \mu \mathrm{l}$ of anti-Taq DNA polymerase $(7 \mu \mathrm{M}), 0.2 \mu \mathrm{l}$ of Taq DNA polymerase $(5 \mathrm{U} / \mu \mathrm{l})$, $2 \mu \mathrm{l}$ of flagged sense primer $(10 \mu \mathrm{M}), 2 \mu \mathrm{l}$ of antisense primer $(10 \mu \mathrm{M})$ (Table 1$), 1.5 \mu \mathrm{l}$ of GC-melt (5 M GCmelt; CLONTECH Laboratories Inc.) and $5 \mu \mathrm{l}$ of genomic DNA solution $(25-250 \mathrm{ng} / \mu \mathrm{l}$ in water). The cycle conditions were 5 seconds at $96^{\circ} \mathrm{C}, 5$ seconds at $60^{\circ} \mathrm{C}$, and 30 seconds at $72^{\circ} \mathrm{C}$, for 50 cycles at slope 9 .

Sequencing. Direct sequencing of the amplified products was performed with the BigDye Terminator Cycle Sequencing Ready Reaction kit (PE Applied Biosystems, Warrington, United Kingdom) and the antisense primer. The products were analyzed on an ABI Prism 377 sequencer (PE Applied Biosystems).

$5^{\prime} R A C E$. To identify the $5^{\prime}$ sequence of the complement factor D cDNA, the $5^{\prime}$ RACE System for Rapid

Table 1

Sequences of primers used for amplification of complement factor-D (CfD) cDNA/gene

\begin{tabular}{|c|c|c|c|c|}
\hline $\begin{array}{l}\text { Fragment } \\
\text { code }\end{array}$ & $\begin{array}{c}\text { Direction } \\
\text { (sense or antisense) }\end{array}$ & Nucleotide sequence & $\begin{array}{l}\text { Nucleotide } \\
\text { number }\end{array}$ & $\begin{array}{l}\text { Amplimer } \\
\text { length (bp) }\end{array}$ \\
\hline FLAG & - & $5^{\prime}$-TGT AAA ACG ACG GCC AGT-3' & - & - \\
\hline \multirow[t]{2}{*}{ Fragment 1a } & $1 \mathrm{~S}$ & 5'-FLAG-TCC TCC TAG GAG CGG CCG CC-3' & $32-51$ & 277 \\
\hline & $11 \mathrm{AS}$ & 5'-ACG TCG TAC AGG CGC TTG GA-3' & $271-290$ & \\
\hline \multirow[t]{2}{*}{ Fragment $1 \mathrm{~b}$} & $11 \mathrm{~S}$ & 5'-FLAG-GTT CTC CTG GGC GCG CAC TC-3' & $232-251$ & 225 \\
\hline & $1 \mathrm{AS}$ & 5'-AGT TCC CGG TGC CAC GTC GC-3' & $419-438$ & \\
\hline \multirow[t]{2}{*}{ Fragment 2} & $2 S$ & $5^{\prime}$-FLAG-CAC ACT GGG CCC TGC TGT GC-3' & $372-391$ & 455 \\
\hline & $2 \mathrm{AS}$ & 5'-CGG GAC TTT GTT GCT TGG GTG ACC C-3' & $784-808$ & \\
\hline \multirow[t]{2}{*}{ Fragment 3} & $3 \mathrm{~s}$ & 5'-FLAG-TGG ACA GCG TCC TGG CCT AG-3' & $743-762$ & 367 \\
\hline & 3 AS & 5'-GGG CAG TGG TGC AAT CAC AAC-3' & $1071-1091$ & \\
\hline \multirow[t]{2}{*}{ Genomic PCR } & $1 \mathrm{gS}$ & 5'-FLAG-AGT AGA GAG GCC GAG GCG CAC GCG CGG-3' & $88-111$ & $\sim 275$ \\
\hline & 1gAS & $5^{\prime}$-AAC C $(C / T) G$ CAC CTT CCC GTC GGC CCT-3' & - & \\
\hline 5'RACE & $1 \mathrm{ASR}$ & 5'-CGC GTC CTC CAG GCA GTG CGC CGC-3' & $190-213$ & - \\
\hline
\end{tabular}


Amplification of cDNA Ends, Version 2.0 (Life Technologies Inc., Gaithersburg, Maryland, USA) was used. The cDNA was synthesized from leukocyte mRNA with the factor $\mathrm{D}$-specific primer 2AS following protocol 6.1.1 for high GC-content transcripts of the $5^{\prime}$ RACE kit. After purification and homopolymeric tailing, a socalled abridged anchor primer (AAP) and 1ASR primer (Table 1) were used for amplification of the RACE product. The amplification method was identical to the genomic PCR, except $5 \mu \mathrm{l}$ of RACE product was used. The cycle conditions were 5 seconds at $96^{\circ} \mathrm{C}, 10$ seconds at $55^{\circ} \mathrm{C}$, and 90 seconds at $72^{\circ} \mathrm{C}$, for 50 cycles at slope 9. This PCR was also performed with the primer pair AAP and 11AS. Both PCR products were sequenced as described above but with the primers 1ASR and AUAP (from the 5'RACE kit).

\section{Results}

Complement assays. Routine examination of the patient's serum revealed that the AP50 titer was below the detection limit in various fresh serum samples, indicating a total absence of alternative pathway activity of the complement system (Table 2). The CH50 titer was in the normal range, as were the concentrations of $\mathrm{C} 3$ and $\mathrm{C} 4$ (Table 2). In addition, immunochemical (double immunodiffusion) tests demonstrated near normal concentrations for factors $\mathrm{H}$ and I and properdin (not shown).

The activity of factor $\mathrm{D}$ was tested with factor $\mathrm{D}$ depleted serum; this revealed that no factor $\mathrm{D}$ activity was present in the patient's serum (Figure 3a). Restoration of the alternative pathway activity was achieved by adding purified factor $\mathrm{D}$ to the patient's serum (Figure $3 b)$. Because a total factor D deficiency was likely, family members of the patient were tested. Table 2 shows that the patient's twin sister, their mother, and a maternal uncle also lacked alternative pathway activity in

\section{Figure 5}

Opsonization of E. coli or N. meningitidis by factor D-deficient serum. (a) The kinetics of E. coli phagocytosis: circles, normal pool serum; upward triangles, serum of propositus $\mathrm{V}: 7$; downward triangles, serum of propositus with added factor $D$. Means \pm SEM of three independent experiments. ANOVA showed $P$ values less than 0.0001 between all means. Differences between results obtained at 20 and 30 minutes with factor D-deficient serum and either normal serum or factor D-deficient serum with added factor $D$ are significant ( $P<0.05$, two-tailed $P$ value). (b) The restoration by factor $\mathrm{D}$ of the E. coli opsonizing defect in all four factor D-deficient sera measured at $10 \%$ serum and 20 minutes of incubation. Open columns, without added factor D; filled columns, with added factor D $(2 \mu \mathrm{g} / \mathrm{ml})$. $\mathrm{V}: 7$, propositus; $\mathrm{V}: 8$, sister of the propositus; IV:8, mother of the propositus; IV:11, maternal uncle of the propositus. (c) The kinetics of N. meningitidis phagocytosis: circles, normal pool serum; upward triangles, serum of propositus V:7; downward triangles, serum of propositus with added factor $D$. Means \pm SEM of five independent experiments. ANOVA showed $P=0.0015$ between all means. Differences between results obtained at 15 and 30 minutes with factor $D$-deficient serum and either normal or factor D-deficient serum with added factor $\mathrm{D}$ are significant $(P<0.02$; two-tailed $P$ value $)$. their serum and that they all had factor D concentrations below the detection limit of the factor D assay $(0.03 \mathrm{mg} / \mathrm{l})$ (Figure 3a). Reconstitution experiments with purified factor $\mathrm{D}$ were performed, and - as with the serum from the propositus - the alternative pathway activity in all three sera was restored by the addition of factor D (not shown).

Some of the other family members showed a normal AP50 titer but a diminished factor D activity (Figure 3a). It is also clear from Table 2 that a considerable number of family members had a factor $\mathrm{D}$ concentration below or in the lower part of the normal range.

DNA analysis. To identify the cause of the factor D deficiency and to clarify the mode of inheritance in this family, sequence analysis was first performed on PCR-amplified cDNA of factor D, derived from mRNA of circulating leukocytes. The results were inconclusive, because very little PCR product was obtained from the factor D-deficient individuals. It was decided, therefore, to amplify exonic sequences of factor D from genomic DNA. However, the $5^{\prime}$ sequences of the human factor $\mathrm{D}$ gene, encoding the signal peptide of factor $D$, have not yet been described. A 5' RACE was performed for this purpose. The results are shown in Figure 4. Based on this
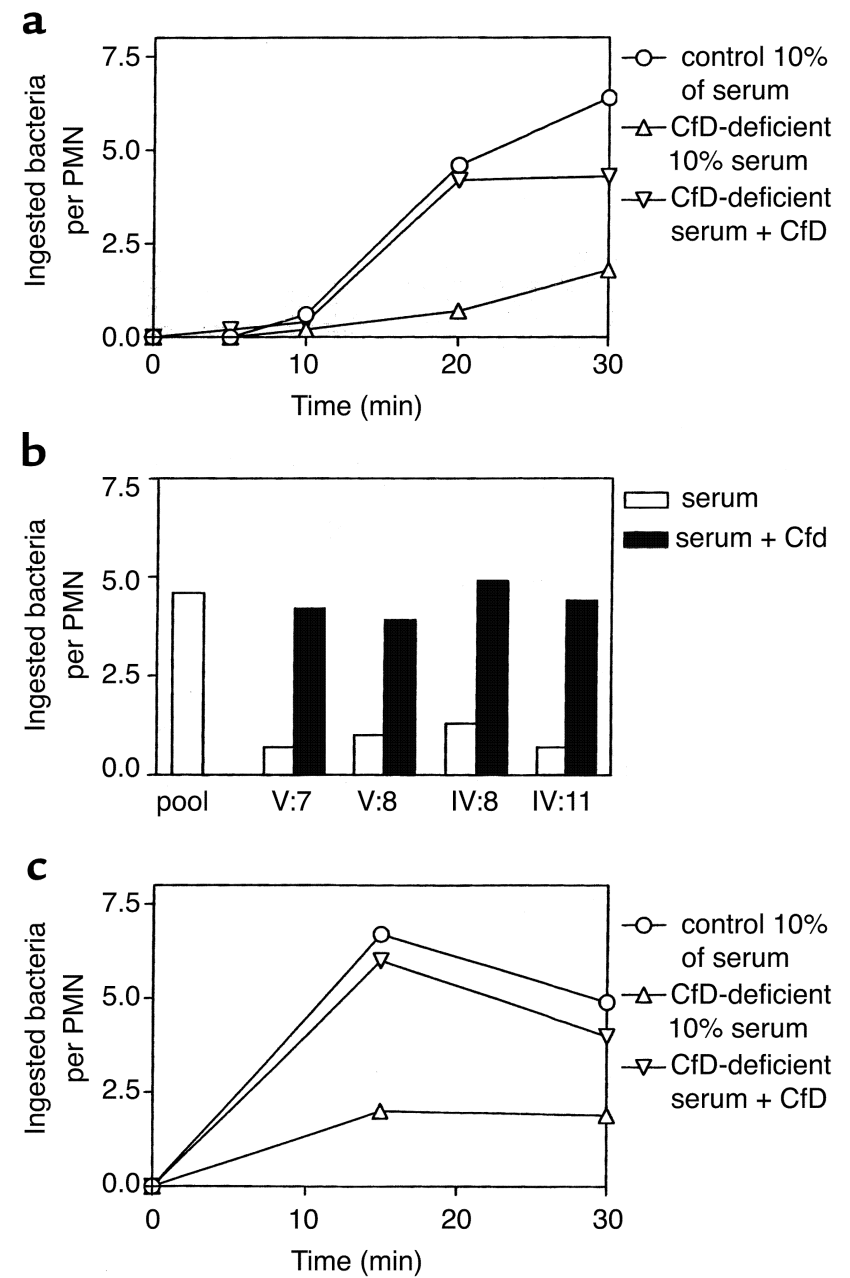
information, appropriate primers were designed and subsequently used to amplify and sequence the genomic exons. This revealed a mutation of the TCG codon for serine 42 into a TAG stop codon (Figure 4) on both alleles in the five factor D-deficient family members and on one allele in 21 of the family members with decreased or low normal factor D levels. Twenty-nine family members with normal factor D levels had no mutation in their factor $\mathrm{D}$ gene. The mode of inheritance appears to be autosomal recessive (Figure 2). The high number of heterozygotes and the occurrence of homozygotes in three generations are explained by the numerous consanguineous marriages in this family. Analysis of 130 alleles from healthy control individuals revealed no abnormality in the codon for serine 42 .

Opsonization studies. To study the effect of the factor $\mathrm{D}$ deficiency on the opsonization of microorganisms that activate the alternative complement pathway, serum-resistant E. coli 054 bacteria were incubated with neutrophils from a healthy volunteer in the presence of various concentrations of normal or factor D-deficient serum. Normal human neutrophils were incubated for 0-30 minutes with $E$. coli 054 or $N$. meningitidis serogroup B, type 15 , subtype P1.5 (isolated from the patient) in the presence of $10 \%$ ( $\mathrm{vol} / \mathrm{vol})$ patient serum or $10 \%$ (vol/vol) normal human pool serum. The uptake of the bacteria by the neutrophils was assessed microscopically. Lower concentrations of the pool serum gave suboptimal opsonization; higher concentrations gave similar opsonization, as did $10 \%$ of the pool serum. The results depicted in Figure 5, a and b, show a strongly decreased phagocytosis of E. coli in the presence of factor D-deficient serum, which was corrected by the addition of purified factor $\mathrm{D}$ to these sera. Figure $5 \mathrm{c}$ shows that the patient's serum also had a decreased capacity to opsonize the Neisseria meningitidis strain isolated from the patient's cerebrospinal fluid, in contrast to normal serum. This defect was also corrected by purified factor $\mathrm{D}$.

\section{Discussion}

Human complement factor D is an obligatory, catalytic component of the alternative pathway of complement activation. The close similarity of enzymatic specificity between mouse adipsin and human complement factor $\mathrm{D}$ has led to the suggestion that adipsin may be the mouse homologue of factor $\mathrm{D}(10,11)$. White et al. have isolated cDNA for human adipsin and demonstrated that this encodes a protein with $98 \%$ amino acid sequence similarity with purified natural human complement factor $\mathrm{D}(2)$.

Data concerning the susceptibility for infections and the mode of inheritance in adults with factor D deficiency are limited to two observations, both from Dutch centers. Kluin-Nelemans et al. found a partial ( $8 \%$ of normal levels) deficiency of factor $\mathrm{D}$ in an adult twin suffering from recurrent bacterial respiratory infections with various microorganisms (12). The mother, a brother, and a sister had normal factor D levels. Hiemstra et al. have described a complete deficiency of complement factor $\mathrm{D}$ in a young man with recurrent Neisseria infections (3). The patient's mother showed a partial factor D deficiency; the patient's sister, father, and maternal grandparents had factor D levels within the normal range. The authors suggested an $\mathrm{X}$-linked mode of inheritance, with a new mutation that had occurred in the mother. In a more recent paper, a 6-day-old neonate was described with a complete factor $\mathrm{D}$ deficiency, suffering from pneumococcal sepsis (13). This report did not provide data on the baby's family. Furthermore, follow-up data were lacking, and the possibility of a late-onset increase in factor $D$ cannot be excluded.

Our report is the first, to our knowledge, to document a mutation in the factor $\mathrm{D}$ gene, resulting in a complete factor D deficiency in a patient suffering from a serious $N$. meningitidis infection, in a relative with a history of bacterial meningitis of unknown origin, and in three of her relatives without a history of (recurrent) infections. The extended family search revealed a high degree of consanguinity, with 21 family members

Table 2

Assay of complement components in serum

\begin{tabular}{|c|c|c|c|c|c|}
\hline & $\begin{array}{c}\mathrm{C} 3 \\
\mathrm{mg} / \mathrm{dl}\end{array}$ & $\begin{array}{c}\mathrm{C} 4 \\
\mathrm{mg} / \mathrm{dl}\end{array}$ & $\underset{\%}{\mathrm{CH} 50}$ & $\begin{array}{l}\text { AP50 } \\
\%\end{array}$ & $\begin{array}{c}\text { factor D } \\
\mathrm{mg} / \mathrm{l}\end{array}$ \\
\hline $\begin{array}{l}\text { Healthy donors, nonfamily } \\
\text { members }(n=60)\end{array}$ & $135 \pm 23$ & $25 \pm 8$ & $100 \pm 25$ & $100 \pm 25$ & $1.39 \pm 0.32$ \\
\hline Family members $\mathrm{C} / \mathrm{C}(n=29)$ & $107 \pm 21$ & $23 \pm 7$ & $92 \pm 16$ & $113 \pm 28$ & $2.22 \pm 0.68$ \\
\hline Family members $\mathrm{A} / \mathrm{C}(n=19)$ & $114 \pm 23$ & $23 \pm 5$ & $104 \pm 19$ & $106 \pm 22$ & $0.92 \pm 0.24^{\mathrm{A}}$ \\
\hline \multicolumn{6}{|l|}{ Family members $\mathrm{A} / \mathrm{A}$} \\
\hline $\mathrm{IV}: 8$ & 141 & 19 & 113 & $<10$ & $<0.03$ \\
\hline IV:11 & 125 & 23 & 116 & $<10$ & $<0.03$ \\
\hline V:7 (propositus) & 121 & 27 & 116 & $<10$ & $<0.03$ \\
\hline $\mathrm{V}: 8$ & 137 & 21 & 112 & $<10$ & $<0.03$ \\
\hline
\end{tabular}

Values are mean \pm SD. Data of III: $18, I V: 25$, and IV:26 are incomplete and are therefore not included. C/C, wild-type factor D gene; A/C, heterozygotes for C125A; A/A, homozygotes for C125A. AStatistically different from the factor D levels found in healthy donors (nonfamily members) and from the factor D levels of family members with the wild-type factor $D$ gene (both $P<0.0001$; two-tailed Mann-Whitney $U$ test). 
heterozygous for the mutation. The factor $\mathrm{D}$ concentration and the molecular analysis showed a good correlation, although some heterozygotes had low-normal factor $\mathrm{D}$ levels (Table 2). This is probably due to the fact that factor $\mathrm{D}$ is an acute-phase protein, leading to a wide range of normal serum values. The mode of inheritance of factor D deficiency is autosomal recessive, which is in accordance with the localization of the factor D gene on chromosome 19 (14), but in contrast to the previously suggested $X$-linked inheritance based on factor $\mathrm{D}$ activity measurements in one patient and only five family members (3).

Our attempts to perform DNA sequence analysis based on the cDNA sequence of human adipsin/factor $D$ failed, because we did not obtain sufficient PCR product from cDNA generated from leukocyte mRNA of the individuals with a complete factor D deficiency. This may be due to very low levels of factor D mRNA in these individuals, caused by instability of the mRNA coding for a protein with a stop codon in the $\mathrm{N}$-terminal region (15). Analysis of the $5^{\prime}$ region of the human factor $\mathrm{D}$ gene revealed a high homology with the mouse adipsin gene (16), namely $71 \%$ at the nucleotide level and $64 \%$ at the amino acid level (Figure 4). As in mice, human factor $\mathrm{D}$ is first expressed as a zymogen, from which an activation peptide is split off before release of the mature, active protein into the circulation (17).

It is remarkable that the propositus in our family suffered from an almost fatal $N$. meningitidis sepsis and that another family member had a history of bacterial meningitis, whereas the other family members with complete or partial factor D deficiency had no history of infections. We have searched for additional defects in the antibacterial defense in the propositus, but we have found no clear differences with the other three living, completely factor D-deficient family members. All four individuals available for further studies had a low concentration of mannose-binding lectin (MBL) in their serum, in three of them (IV:8, V:7, and V:8) correlating with the well-known codon $57 \mathrm{G} \rightarrow$ A mutation in one allele of the MBL gene, predicting Gly57 $\rightarrow$ Glu (18). The effect of this decreased MBL concentration on the opsonization of $N$. meningitidis serogroup B cannot be tested in vitro, because the capsule of these bacteria prohibits binding of MBL (19). However, after removal of the lipo-oligosaccharides and the sialic acids from the capsular polysaccharides in a host, MBL may still be able to promote deposition of opsonic complement fragments on these bacteria. Nevertheless, this does not explain the difference in clinical expression between patient V:7 and her mother IV:8 or her sister V:8. We also determined by genetic analysis three polymorphisms in Fcy receptors in the four completely factor $\mathrm{D}$-deficient individuals (20-22). The patient, her mother, and her uncle IV: 11 were found to be heterozygotes for the $131 \mathrm{H}$ and the 131R allotypes of FcyRIIa, whereas the patient's sister was homozygous for the $131 \mathrm{H}$ allotype. The $131 \mathrm{R}$ allotype does not react with $\mathrm{IgG}_{2}-$ opsonized microorganisms, in contrast to the $131 \mathrm{H}$ allotype (23). Similarly, the patient, her mother, and her uncle were homozygotes for the NA2 allotype of FcyRIIIb, whereas the patient's sister was heterozygous for the NA1 and the NA2 allotype. The NA2 allotype reacts less efficiently with IgG $_{1}$-opsonized microorganisms than does the NA1 allotype (24). Finally, the patient and her mother were found to be homozygotes for the $158 \mathrm{~V}$ allotype of Fc $\gamma \mathrm{RIII}$, whereas the patient's sister and her uncle were heterozygotes for $158 \mathrm{~V}$ and $158 \mathrm{~F}$. The $158 \mathrm{~V}$ allotype binds more $\mathrm{IgG}_{1}, \mathrm{IgG}_{3}$, and $\mathrm{IgG}_{4}$ than does the $158 \mathrm{~F}$ allotype of this receptor (22). Thus, the reason for the difference in clinical expression between these four factor $\mathrm{D}$-deficient individuals remains to be established.

The lack of obvious infections in three of the five completely factor $\mathrm{D}$-deficient individuals in our family also contrasts with the previously reported cases of complete factor D deficiency, who all had recurrent bacterial infections. Firm conclusions about the vulnerability to bacterial infections of persons with complete factor D deficiency are hampered by the low number of individuals reported with complete factor D deficiency. All persons with complete factor D deficiency presented with AP50 titers below the detection limit. Our understanding of the prevalence and pathogenesis of factor D deficiency can be improved by the determination of AP50 titers in young patients with Neisseria infections.

Our patient and the three living family members with complete factor $\mathrm{D}$ deficiency received vaccinations against meningococcal and pneumococcal infections and Haemophilus influenzae type B, which result$\mathrm{ed}$ in adequate $\mathrm{Ab}$ responses. The finding of complete factor $\mathrm{D}$ deficiency in a deceased family member with a history of bacterial meningitis supports the concept that factor D deficiency is a significant risk factor for serious invasive bacterial diseases including meningitis. The use of prophylactic antibiotics in complete factor $\mathrm{D}$-deficient individuals is questionable. The risk of selection of penicillin-resistant bacteria should be balanced against the possible benefit of protection against life-threatening infections, which will not occur in every person with complete factor D deficiency. The recent finding of the second case of a serious episode of meningitis in a patient with complete factor D deficiency in this family has led to a reconsideration of our initial decision not to use prophylactic antibiotics in people with complete factor D deficiency. The absence of any history of infections in individuals with a partial factor D deficiency renders increased susceptibility to infections with encapsulated bacteria unlikely. Therefore, in our opinion, an extensive vaccination program or the use of prophylactic antibiotics in individuals with a partial factor $\mathrm{D}$ deficiency is not necessary.

Finally, decreased factor D activity has been found in several mouse and rat models pertaining to obesity. However, the previously suggested role of factor $\mathrm{D}$ in the regulation of the energy balance and in the patho- 
genesis of obesity is in contrast with the absence of obesity in our patient and her relatives with complete factor $\mathrm{D}$ deficiency $(11,25)$. It is more likely that part of the factor $\mathrm{D}$ production occurs in adipocytes and that this production is impaired in patients with obesity (26).

\section{Acknowledgments}

We thank Thea de Rijk, Judy Geissler, Jan Dekker, Martin de Boer, Shirley Janssen, Cindy Bennemeer, and Sandra Remijn for excellent technical help.

1. Ochs, H.D., Wedgwood, R.J., Frank, M.M., Heller, S.R., and Hosea, S.W. 1983. The role of complement in the induction of antibody responses. Clin. Exp. Immunol. 53:208-216.

2. White, R.T., et al. 1992. Human adipsin is identical to complement factor $\mathrm{D}$ and is expressed at high levels in adipose tissue. J. Biol. Chem. 267:9210-9213.

3. Hiemstra, P.S., et al. 1989. Complete and partial deficiencies of complement factor D in a Dutch family. J. Clin. Invest. 84:1957-1961.

4. Figueroa, J., Andreoni, J., and Densen, P. 1993. Complement deficiency states and meningococcal disease. Immunol. Res. 12:295-311.

5. Meyer, M.M. 1961. In Experimental immunochemistry. 2nd edition. Kabat, E.A., and Meyer, M.M., editors. Charles C. Thomas. Springfield, Illinois, USA. $133-240$

6. Klerx, J.P., Beukelman, C.J., van Dijk, H., and Willers, J.M. 1983. Microassay for colorimetric estimation of complement activity in guinea pig, human and mouse serum. J. Immunol. Methods. 63:215-220.

7. Praz, F., Roque Antunes Barreira, M.C., and Lesavre, P. 1982. A one-step procedure for preparation of classical pathway (factor D) depleted serum. J. Immunol. Methods. 50:227-231.

8. Chirgwin, J.M., Przybyla, A.E., MacDonald, R.J., and Rutter, W.J. 1979 Isolation of biologically active ribonucleic acid from sources enriched in ribonuclease. Biochemistry. 18:5294-5299.

9. Bolscher, B.G.J.M., de Boer, M., de Klein, A., Weening, R.S., and Roos, D. 1991. Point mutations in the $\beta$-subunit of cytochrome $b_{558}$ leading to $X$ linked chronic granulomatous disease. Blood. 77:2482-2487.

10. Niemann, M.A., Bhown, A.S., Bennett, J.C., and Volonakis, J.E. 1984. Amino acid sequence of human D of the alternative complement pathway. Biochemistry. 23:2482-2486.

11. Rosen, B.S., et al. 1989. Adipsin and complement factor D: an immune related defect in obesity. Science. 244:1483-1487.
12. Kluin-Nelemans, H.C., van Velzen-Blad, H., van Helden, H.P.T., and Daha, M.R. 1984 Functional deficiency of complement factor D in a monozygous twin. Clin. Exp. Immunol. 58:724-730.

13. Weiss, S.J., Ahmed, A.E., and Bonagura, V.R. 1998. Complement factor $\mathrm{D}$ deficiency in an infant first seen with pneumococcal neonatal sepsis. J. Allergy Clin. Immunol. 102:1043-1044.

14. Arlaud, G.J., et al. 1998. The atypical serine proteases of the complement system. Adv. Immunol. 69:249-307.

15. Cooper, D.N. 1993. Human gene mutations affecting RNA processing and translation. Ann. Med. 25:11-17.

16. Cook, K.S., Groves, D.L., Min, H.Y., and Spiegelman, B.M. 1985. A developmentally regulated mRNA from 3T3 adipocytes encodes a novel serine protease homologue. Proc. Natl. Acad. Sci. USA. 82:6480-6484.

17. Yamauchi, Y., Stevens, J.W., Macon, K.J., and Volonakis, J.E. 1994. Recombinant and native zymogen forms of human complement factor D. J. Immunol. 152:3645-3653.

18. Lipscombe, R.J., et al. 1992. High frequencies in African and non-African populations of independent mutations in the mannose binding protein gene [erratum 1993, 2:342]. Hum. Mol. Genet. 1:709-715.

19. Jack, D.L., et al. 1998. Activation of complement by mannose-binding lectin on isogenic mutants of Neisseria meningitidis serogroup B. J. Immunol. 160:1346-1353.

20. Osborne J.M., Chacko, G.W., Brandt, J.T., and Anderson, C.L. 1994. Ethnic variation in frequency of an allelic polymorphism of human Fc $\gamma$ RIIA determined with allele specific oligonucleotide probes. J. Immunol. Methods. 173:207-217.

21. De Haas, M., Kleijer, M., van Zwieten, R., Roos, D., and von dem Borne, A.E. 1995. Neutrophil Fc $\gamma$ RIIIb deficiency, nature and clinical consequences: a study of 21 individuals from 14 families. Blood. 86:2403-2413.

22. Koene, H.R., et al. 1997. Fc $\gamma$ RIIIa-158V/F polymorphism influences the

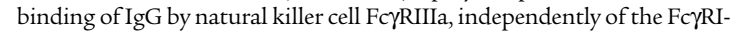
IIa-48L/R/H phenotype. Blood. 90:1109-1114.

23. Bredius, R.G., et al. 1993. Phagocytosis of Staphylococcus aureus and Haemophylus influenzae type B opsonized with polyclonal human $\operatorname{IgG}_{1}$ and $\mathrm{IgG}_{2}$ antibodies. Functional hFc $\gamma$ RIIa polymorphisms to $\mathrm{IgG}_{2} . \mathrm{J}$. Immunol. 151:1463-1472.

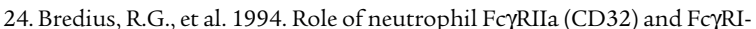
IIb (CD16) polymorphic forms in phagocytosis of human $\mathrm{IgG}_{1^{-}}$and $\mathrm{IgG}_{3}$-opsonized bacteria and erythrocytes. Immunology. 83:624-630.

25. Maslowska, M., et al. 1999. Plasma acylation stimulating protein, adipsin and lipids in non-obese and obese populations. Eur. J. Clin. Invest. 29:653-656.

26. Choy, L.N., Rosen, B.S., and Spiegelman, B.M. 1992. Adipsin and an endogenous pathway of complement from adipose cells. J. Biol. Chem. 267:12736-12741. 